\title{
Influence of Cutting Tool Material on the Surface Roughness of AlMgSi Aluminium Alloy
}

Júlia Hricová

Faculty of Environmental and Manufacturing Technology, Technical University in Zvolen, Studentska 26, 96053 Zvolen, Slovakia, julia.hricova@tuzvo.sk

Milling is one of the most universal operations in machining processes because it can remove the redundant part of material efficiently, and moreover, it can produce almost all kinds of contour surfaces with a high quality finish. Surface roughness plays an important role in determining the product quality since it strongly influences the performance of mechanical parts as well as production cost. Many types of cutting materials are used as tool materials in today's metalworking industry. Selecting the proper cutting tool material for a specific machining application can provide substantial advantages including increased productivity, improved quality and ultimately reduced costs. This article is aimed at determining the influence of different tool materials on surface roughness of AlMgSi aluminium alloy after side milling with using of the analysis of variance (ANOVA).

Keywords: aluminium alloy, cutting tool material, milling, surface roughness

\section{References}

[1] SUTHERLAND, J. W., A Dynamic Model of the Cutting Force System in the End Milling Process, Sensors and Controls for Manufacturing, 1988, Vol. 33, pp. 53-62.

[2] WANG M. Y.; CHANG, H. Y. Experimental study of surface roughness in slot end milling. International Journal of Machine Tools and Manufacture, 2004, Vol. 44, pp. 51-7.

[3] COLAK, O. Milling surface roughness prediction using evolutionary programming methods. Materials and Design, 2007, Vol. 28, pp. 657-666.

[4] DEGARMO, E. P.; BLACK J. T.; KOSHERS, R. A. Materials and Processes in manufacturing, 9th edition, USA: Wiley, 2003.

[5] DAVIS, J.R. Tool Materials (ASM Specialty Handbook). Ohio: ASM International, Materials Park, 2005.

[6] PLANSEE TIZIT, Ltd., Austria. Tools for aluminium machining, 2013.

[7] ASILTURK, I.; AKKUS, H. Determining the effect of cutting parameters on surface roughness in hard turning using the Taguchi method. Measurement, 2011, Vol. 44, pp. 1697-1704.

[8] ASLAN, E.; CAMUŞCU, N.; BINGÖREN, B. Design optimization of cutting parameters when turning hardened AISI 4140 (63 HRC) with Al2O3+TiCN mixed ceramic tool. Mater. Design, 2007, Vol. 28, pp. 1618-1622.

[9] KOVÁČ, M.; ZVONČAN, M.; BEŇO, M.; PETERKA, J. Experimental view on surface integrity during conventional and high-speed milling of Aluminium alloy AlMgSil EN 6082. In Comec 2012: VII International Scientific Conference of Mechanical Engineering. November 5th to 8th 2012, Villa Clara, Cuba. Central University of Las Villas, 2012, 6p. ISBN 978-959250-757-9.

[10] JERSÁK, J.; GANEV, N.; KOVALČÍK, J.; DVOŘÁČKOVÁ, Š.; KARÁSEK, J.; HOTǍ̌, A. Surface integrity of hardened bearing steel after milling. Manufacturing Technology, 2010, Vol. 10, pp. 80-87.

[11] KOLAŘÍK, K.; GANEV, N.; PALA, Z.; BARCAL, J.; BAKALOVA, T.; ZEMAN, P. Investigation of Milled Surfaces of High-alloy Tools Steels in Respect to the Cutting Speed. Manufacturing Technology, 2008, vol. 9, pp. 35-39.

[12] ŠUGÁR, P.; ŠUGÁROVÁ, J.; PETROVIČ, J. Surface roughness analysis of metal spun parts. Advanced Materials Research, 2013, vols. 652-654, pp. 2006-2009.

[13] NOVÁK, M.; LATTNER, M.; RŮŽIČKA, L.; HOLEŠOVSKÝ, F. Grinding and surface quality parameters at automotive parts machining. Manufacturing Technology, 2010, Vol. 10, pp. 36-38.

[14] ŤAVODOVÁ, M. The surface quality of materials after cutting by abrasive water jet evaluated by selected methods. Manufacturing Technology, 2013, Vol. 13, No. 2, pp. 236-241.

[15] DMG/MORI SEIKI Co. Ltd., product catalogue (2013)

[16] BENARDOS P. G.; VOSNIAKOS G. Predicting surface roughness in machining: a review. International Journal of Machine Tools and Manufacture, 2003, Vol. 43, pp. 833-44.

[17] OCHODEK, V.; NESLUŠAN, M.; ROZSÍPAL, M.; ŠÍPEK, M. Non-destructive analysis of surface integrity in turning and grinding operations. Manufacturing Technology, 2010, Vol. 10, pp. 57-64.

[18] SHARMA, A.V.N.L.; SATYANARAYANA RAJU, P.; GOPICHAND, A.; SUBBAIAH, K.V. Optimization of cutting parameters on mild steel with HSS \& Cemented carbide tipped tools using ANN. International Journal of Research in Engineering and Technology, 2012, Vol. 1, pp. 226-228. 